\title{
Alumina Ceramics Corrosion Behaviour ESTIMATED BY ARTIFICIAL NEURAL NETWORKS
}

\author{
ZMAK, I. \& CURKOVIC, L.
}

Abstract: Artificial neural network models were used for estimation of corrosion behaviour of a cold isostatically pressed (CIP) high-purity alumina ceramics in aqueous $\mathrm{HCl}$ solution. Corrosion tests were performed with initial mass concentrations of $\mathrm{HCl}$ aqueous solution of 2, 10 and $20 \mathrm{wt}$. \% at room temperature. Immersion times were 24, 48, 72, 120, 168 and 240 hours. Chemical stability was monitored by the amount of $\mathrm{Al}^{3+}, \mathrm{Mg}^{2+}, \mathrm{Ca}^{2+}, \mathrm{Na}^{+}, \mathrm{Si}^{4+}$ and $\mathrm{Fe}^{3+}$ ions eluted in different concentrations of $\mathrm{HCl}$ solution by means of atomic apsorption spectrometry (AAS), expressed as the amount of eluted ions in $\mathrm{mg}$ per square centimetre of test alumina area $\left(\mu \mathrm{g} \mathrm{M}^{\mathrm{nt}} / \mathrm{cm}^{2}\right)$. The initial $\mathrm{HCl}$ aqueous solution concentration and immersion time were inputs to the neural network, and the output was the amount of eluted ions ( $\mu \mathrm{g} \mathrm{M}^{\mathrm{n}} / \mathrm{cm}^{2}$ ). Error back-propagation learning algorithm, with Levenberg-Marquardt method, was applied to the feed forward neural networks.

Key words: alumina ceramics, acid corrosion, corrosion kinetics, artificial neural networks, estimation
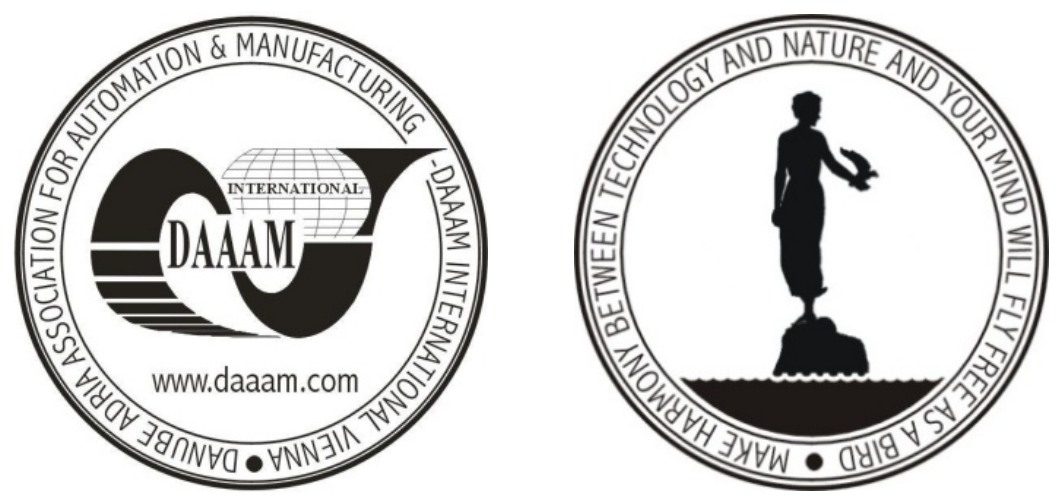

Authors' data: Dr. Sc. Zmak, I[rena]; Prof. Dr. Sc. Curkovic, L[idija], University of Zagreb, Faculty of Mechanical Engineering and Naval Achitecture, Ivana Lucica 5, 10000,Zagreb, Croatia, irena.zmak@fsb.hr, lidija.curkovic@fss.hr

This Publication has to be referred as: Zmak, I[rena] \& Curkovic, L[idija] (2009). Alumina Ceramics Corrosion Behaviour Estimated by Artificial Neural Networks, Chapter 54 in DAAAM International Scientific Book 2009, pp. 549-560, B. Katalinic (Ed.), Published by DAAAM International, ISBN 978-3-901509-69-8, ISSN 17269687, Vienna, Austria

DOI: $10.2507 /$ daaam.scibook.2009.54 